Article

\title{
Electrochemical, Spectroscopic, and Computational Investigations on Redox Reactions of Selenium Species on Galena Surfaces
}

\author{
Peter Cook ${ }^{\mathbb{D}}$, YoungJae Kim *(D), Ke Yuan ${ }^{\dagger}$, Maria C. Marcano ${ }^{\circledR}$ and Udo Becker ${ }^{(D)}$ \\ Department of Earth and Environmental Sciences, University of Michigan, Room 2534, North University Bldg., \\ 1100 N University Ave, Ann Arbor, MI 48109-1005, USA \\ * Correspondence: youngjkm@umich.edu; Tel.: +1-734-615-6894 \\ + Present address: Oak Ridge National Laboratory, 1 Bethel Valley Rd, Oak Ridge, TN 37830, USA.
}

Received: 15 June 2019; Accepted: 13 July 2019; Published: 15 July 2019

check for updates

\begin{abstract}
Despite previous studies investigating selenium (Se) redox reactions in the presence of semiconducting minerals, Se redox reactions mediated by galena $(\mathrm{PbS})$ are poorly understood. In this study, the redox chemistry of Se on galena is investigated over a range of environmentally relevant Eh and $\mathrm{pH}$ conditions (+0.3 to $-0.6 \mathrm{~V}$ vs. standard hydrogen electrode, $\mathrm{SHE}$; $\mathrm{pH} 4.6$ ) using a combination of electrochemical, spectroscopic, and computational approaches. Cyclic voltammetry (CV) measurements reveal one anodic/cathodic peak pair at a midpoint potential of $+30 \mathrm{mV}$ (vs. SHE) that represents reduction and oxidation between $\mathrm{HSeO}_{3}{ }^{-}$and $\mathrm{H}_{2} \mathrm{Se} / \mathrm{HSe}^{-}$. Two peak pairs with midpoint potentials of -400 and $-520 \mathrm{mV}$ represent the redox transformation from $\mathrm{Se}(0)$ to $\mathrm{HSe}^{-}$and $\mathrm{H}_{2}$ Se species, respectively. The changes in Gibbs free energies of adsorption of Se species on galena surfaces as a function of Se oxidation state were modeled using quantum-mechanical calculations and the resulting electrochemical peak shifts are $\left(-0.17 \mathrm{eV}\right.$ for $\mathrm{HSeO}^{3-} / \mathrm{H}_{2} \mathrm{Se},-0.07 \mathrm{eV}$ for $\mathrm{HSeO}^{3-} / \mathrm{HSe}^{-}$, $0.15 \mathrm{eV}$ for $\mathrm{Se}(0) / \mathrm{HSe}^{-}$, and $-0.15 \mathrm{eV}$ for $\left.\mathrm{Se}(0) / \mathrm{H}_{2} \mathrm{Se}\right)$. These shifts explain deviation between Nernstian equilibrium redox potentials and observed midpoint potentials. X-ray photoelectron spectroscopy (XPS) analysis reveals the formation of Se(0) potentials below $-100 \mathrm{mV}$ and Se(0) and Se(-II) species at potentials below $-400 \mathrm{mV}$.
\end{abstract}

Keywords: selenium redox transformation; galena; elemental selenium; selenide; electrochemistry; computational modeling

\section{Introduction}

While a vital nutrient at low concentrations, the capacity of selenium (Se) to act as a toxic contaminant has been evinced by cases such as the Kesterson reservoir in California where high concentrations of Se in sediments and aquatic systems have led to increased wildlife mortality rates and birth defects [1,2]. Owing to the chemical similarity to sulfur (S), such hazardous accumulations in the environment are often linked to the weathering of coal [3] and Se-bearing sulfide minerals [4,5]. Moreover, long-lived radionuclides of Se (e.g., ${ }^{79} \mathrm{Se}$ ) can be introduced to the environment where effluents are generated from spent nuclear fuel or reprocessing this fuel [6].

The mobility and fate of Se in the environment is highly dependent on the oxidation state which dictates factors such as sorption affinities and solubility [4]. For example, Se(VI) and Se(IV) species are dominant under oxidizing conditions and are not only more bioavailable and toxic than reduced forms, but also more soluble granting them greater mobility [4] (Figure 1). Under reducing conditions, Se is found as various $\mathrm{Se}(-\mathrm{II})$ species in addition to insoluble $\mathrm{Se}(0)$. While $\mathrm{Se}(-\mathrm{II})$ can occur as soluble $\mathrm{H}_{2} \mathrm{Se} / \mathrm{HSe}^{-}$species, it also occurs as insoluble metallic selenides such as clausthalite (PbSe) or ferroselite $\left(\mathrm{FeSe}_{2}\right)$, and as an incorporated species in a number of sulfides. 


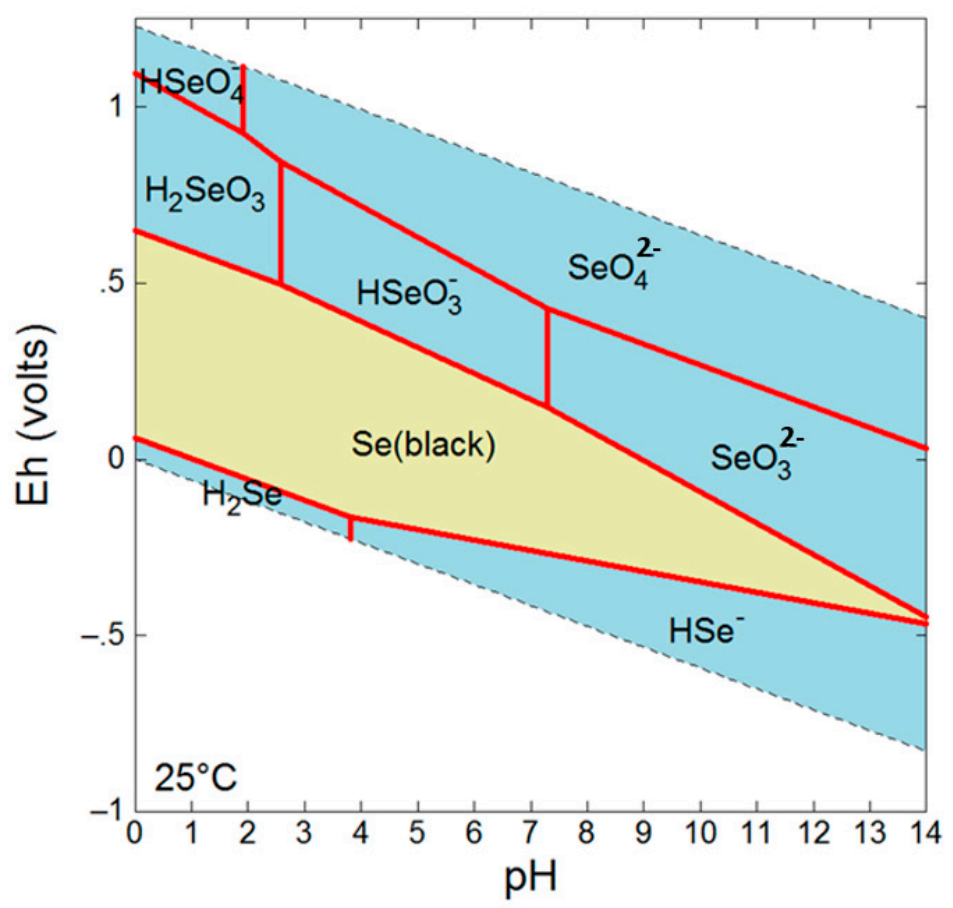

Figure 1. Eh-pH diagram for Se at $10 \mathrm{mM}, 25^{\circ} \mathrm{C}$.

Semiconducting minerals are not only naturally occurring in the environment but are also viable electron sources and sinks and allow for "conducting" electrons between redox-active species adsorbed some nm away from each other [7-15]. Consequently, interactions between contaminants and semiconducting minerals pose the chance for mobilization or immobilization by mediating redox reactions which alter the speciation of the contaminant and therefore its behavior [16]. With a band gap of $0.4 \mathrm{eV}$ [17], galena ( $\mathrm{PbS}$ ) is not only a viable semiconducting mineral, but also one that offers particular geochemical relevance as a plausible substrate for Se interactions due to the common accumulations of Se in sulfide minerals $[4,5,18]$.

To date, the geologic occurrence and distribution of Se in sulfide mineral-rich conditions have been reported $[2,3,5]$. In the literature, however, electrochemical investigations of Se redox transformation have mainly been limited to interactions with materials such as gold (Au) [19-25], platinum (Pt) [26,27], and silver (Ag) [22,28], offering little geochemical relevance. The role of natural semiconducting minerals such as pyrite $\left(\mathrm{FeS}_{2}\right)$ and magnetite $\left(\mathrm{Fe}_{3} \mathrm{O}_{4}\right)$ in Se redox cycling has been experimentally investigated [29-32]; however, the research approach has been limited to batch experiments combined with spectroscopic analysis, and, especially, little is known about interactions between Se and galena.

The goal of the present study is to identify Se redox reactions mediated by galena surfaces over a range of environmentally relevant $\mathrm{Eh}$ and $\mathrm{pH}$ conditions (+0.3 to $-0.6 \mathrm{~V}$; $\mathrm{pH} 4.6)$ and to characterize the effect of galena as a mediating substrate on those reactions. Results from this study will provide implications for the fate and mobility of Se in the environment not only by identifying the specific physicochemical conditions under which speciation changes occur, but also by accounting for how those conditions deviate from expected theoretical conditions. Finally, this paper aims to demonstrate a useful combination of experimental and theoretical techniques and, for these purposes, electrochemical, spectroscopic and computational approaches have been used as outlined below.

Cyclic voltammetry $(\mathrm{CV})$ measurements were performed using a galena electrode and the collected data were analyzed to identify specific redox species responsible for electric signals at given $\mathrm{pH}$ and Eh. The use of electrochemical preparation allows the ability to quantify various redox parameters such as reduction potential, chemical reversibility, and the oxidants and reductants participating in specific reactions. It is important to note that in all experiments performed in this study, galena is not the primary electron donor in the reduction processes described, but rather transmits electrons 
from and to the electrochemical setup. In addition, galena catalyzes the reaction by helping in the dehydration of absorbing species from solution and by the potential overlap of orbitals between the mineral surface and the redox-active orbitals of the absorbing species. Even if a Se-reducing electron originates from an S 3p orbital (i.e., Sulfur 3p orbital), the missing S 3p electron will be replaced by an electron from the electrode.

The adsorption modes of Se species with different oxidation states on galena slabs were simulated based on molecular orbital modeling. Energetic contributions of adsorption are included in evaluating Se redox transformation mediated by galena and deviation between equilibrium reduction potentials and observed midpoint potentials are determined using calculated adsorption Gibbs free energies. Finally, X-ray photoelectron spectroscopy (XPS) was employed to acquire direct evidence for Se redox reactions catalyzed by the galena electrode by determining the composition ratios of different Se species on the galena surface.

\section{Methods}

\subsection{Sample Characterization}

Galena sourced from Missouri was characterized using scanning electron microscope-energy dispersive X-ray spectroscopy (SEM-EDS) using a $15 \mathrm{kV}$ accelerating voltage and a $112.6 \mu \mathrm{A}$ beam current (Figure 2). In addition to lead $(\mathrm{Pb})$ and $\mathrm{S}$, copper $(\mathrm{Cu})$ impurities were detected which is commonly found in galena originating from Missouri [33-35]. The dominant form of powdered galena is cubic, which represents cleaving along (100) planes.

\subsection{Voltammetry}

Voltammetry was conducted in a conventional three-electrode cell controlled by an Princeton Applied Research EG\&G model 263A potentiostat with Powersuite software. A Pt counter electrode (Sigma Aldrich) and $\mathrm{Ag} / \mathrm{AgCl}$ reference electrode were used (CH Instruments); however, all potentials quoted in this study are with respect to the SHE. A powder microelectrode (PME) was used as the working electrode which acts effectively as a cleaved mineral electrode of greater surface area [36]. The increased surface area on a relatively small volume allows for relatively fast reaction kinetics which is important for redox processes in cyclic voltammetry that happen at a second to minute timescale. A PME was prepared by conventional glass blowing techniques and was composed of a Pt wire encased in soda lime glass with the Pt wire exposed flush to the end of the electrode. A cavity of $100 \mu \mathrm{m}$ diameter (dictated by the diameter of the Pt wire) and a $\sim 20 \mu \mathrm{m}$ depth was made by etching the exposed $\mathrm{Pt}$ in aqua regia $\left(\sim 80^{\circ} \mathrm{C}\right)$ for $\sim 2.5 \mathrm{~h}$ [37]. The cavity was packed by tapping the electrode in galena powdered in an agate mortar and pestle, and the powder was removed from the cavity after use via sonication.

Unless otherwise stated, voltammetry was performed on freshly powdered, pristine galena in $10 \mathrm{mM} \mathrm{Na}_{2} \mathrm{SeO}_{3}+100 \mathrm{mM} \mathrm{NaCl}$ adjusted to $\mathrm{pH} 4.6$ at $50 \mathrm{mV} / \mathrm{s}$ initiating from the open circuit potential (OCP) in the positive-going direction. The OCP $(\sim 110 \mathrm{mV} \pm 5 \mathrm{mV})$ was monitored for $30 \mathrm{~s}$ before initiating each scan. Solutions of any $\mathrm{pH}$ were adjusted using $\mathrm{HCl}$ and $\mathrm{NaOH}$. All reagents (excluding galena) were obtained from Sigma Aldrich. Solutions and were sparged with argon (Ar) gas for $30 \mathrm{~min}$ prior to voltammetry to remove dissolved oxygen.

On voltammograms, anodic and cathodic peaks are denoted with an " $\mathrm{A}$ " and " $\mathrm{C}$ ", respectively. The midpoint potential $\left(\mathrm{E}_{\mathrm{mid}}\right)$ of the anodic $\left(\mathrm{E}_{\mathrm{A}}\right)$ and cathodic $\left(\mathrm{E}_{\mathrm{C}}\right)$ peaks comprising a redox couple was defined as $E_{\text {mid }}=\frac{1}{2}\left(E_{A}+E_{C}\right)$. Peak areas and peak currents were obtained using the Origin8.5 plotting software (OriginLab Corporation, Northhampton, USA). For these purposes, peaks were defined by either the two major inflection points or local minima or maxima bounding the peak of interest determined using a Savitzky-Golay smoothing function for first and second derivatives. Using these bounds, peak areas were obtained through integration and peak currents by subtracting 
the apparent peak current from that occurring along its baseline. Unless otherwise stated, peak charges and potentials are taken from the final cycle of cyclic voltammograms.

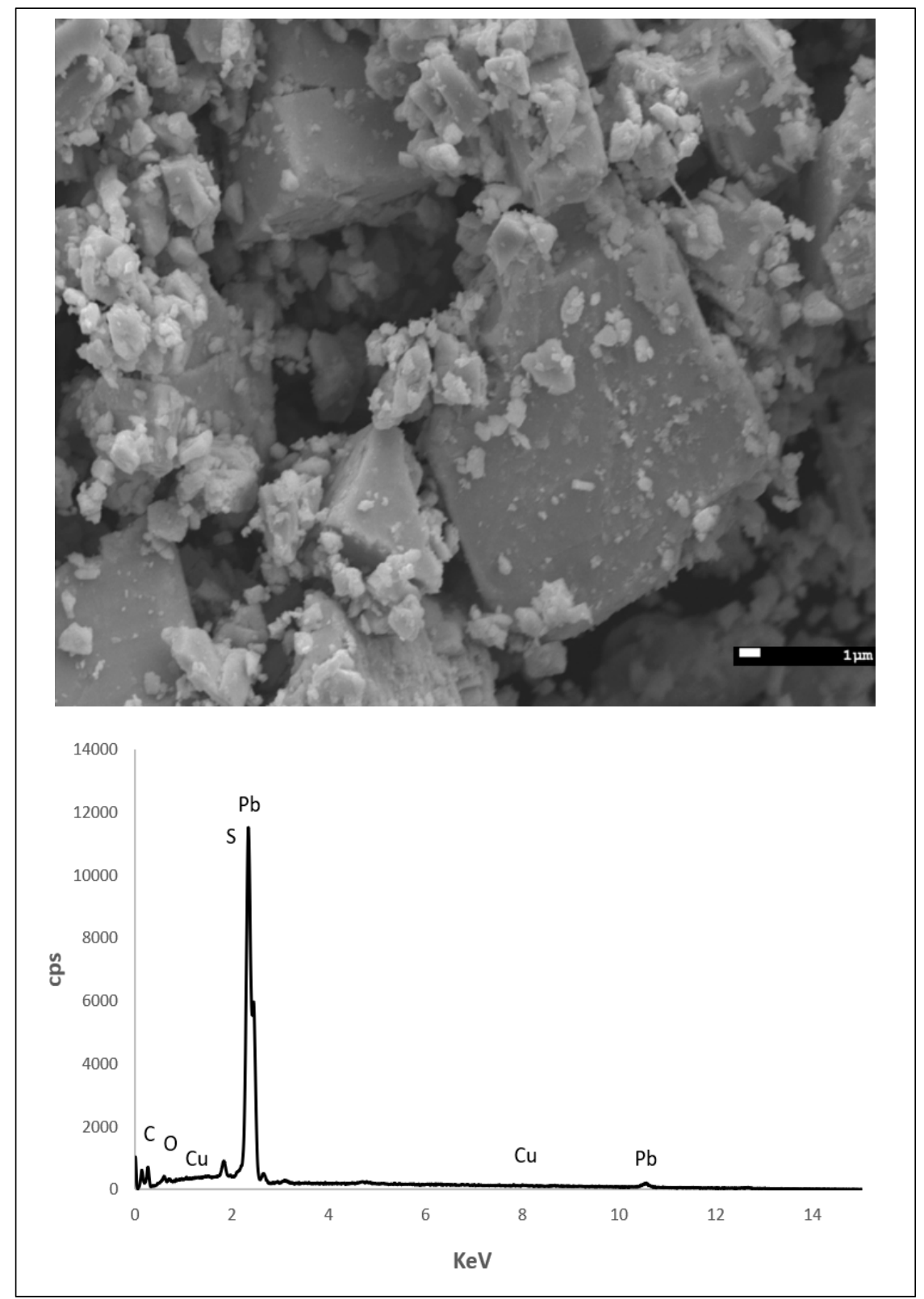

Figure 2. Scanning electron microscope-energy dispersive X-ray spectroscopy (SEM-EDS) image of powdered galena (above) and the resulting spectrum (below). In addition to $\mathrm{Pb}$ and $\mathrm{S}, \mathrm{Cu}$ was detected which is an impurity commonly reported for galena sourced from Missouri.

\subsection{X-Ray Photoelectron Spectroscopy (XPS)}

XPS spectra were obtained using a Kratos Axis Ultra X-ray photoelectron spectrometer with a monochromatized $\mathrm{Al} \mathrm{K \alpha}$ source $(1486.6 \mathrm{eV})$ primed to $8 \mathrm{~mA}$ and $14 \mathrm{kV}$ at no more than $5 \times 10^{-7}$ Torr. Core spectra obtained using a $20 \mathrm{eV}$ pass energy with $0.1 \mathrm{eV}$ resolution were calibrated with respect to the $C 1$ s spectrum of adventitious carbon of each respective sample assuming a binding energy of $284.8 \mathrm{eV}$. Peak fitting and calculation of atomic ratios were performed using CasaXPS 2.3.17 software (Casasoftware Ltd, Teignmouth, UK) and the relative sensitivity factors provided by [38]. Due to the small diameter of the PME, XPS analysis was conducted on bulk galena electrodes prepared by mounting cleaved galena (polished to 1200 grit) to a copper wire via conductive silver paste (Ted 
Pella Inc., Redding, CA, USA) and insulated with non-conductive epoxy (Loctite). Bulk electrodes were polarized at potentials of interest (see Section 3.2) for $30 \mathrm{~min}$ in solution containing $10 \mathrm{mM}$ $\mathrm{Na}_{2} \mathrm{SeO}_{3}+100 \mathrm{mM} \mathrm{NaCl}$ and adjusted to $\mathrm{pH}$ 4.6. After polarization, bulk electrodes were stored in an anaerobic glove bag $\left(5 \% \mathrm{H}_{2}+95 \% \mathrm{~N}_{2}\right)$ for no more than two hours before being transferred into the spectrometer where evacuation could begin. Samples were not rinsed or further treated at any point after polarization. Analytical grade $\mathrm{Na}_{2} \mathrm{SeO}_{4}, \mathrm{Na}_{2} \mathrm{SeO}_{3}$, and $\mathrm{Se}^{0}$ reagents (Sigma Aldrich) were used as reference standard materials.

\subsection{Calculation of Adsorption}

The Gaussian 09 package was used to model the atomic structures and adsorption energies of possible surface species based on molecular orbital calculation. All calculations were made at B3LYP [39,40] and LANL2DZ [41-43] level. B3LYP is a hybrid method of density functional theory (DFT, to included electron correlation) and Hartree-Fock (HF, to approximate electron exchange well) approach. In order to approximate polarization due to bonding additional polarization functions were added (extra basis functions containing no electrons). LANL2DZ uses an all-electron description for atoms of the first row elements and small-core relativistic effective-core potentials (RECP) of inner electrons, combined with double-zeta functions for the valence electrons of heavier atoms of elements such as $\mathrm{S}, \mathrm{Se}$, and $\mathrm{Pb}$ [44]. These computational parameters have been successfully applied to calculating systems involving galena or Se molecules [44-46].

Modeling adsorbate structures on galena (Fm3m space group) was performed on a $4 \times 4 \times 2$ atoms $\mathrm{PbS}$ cluster. This cluster represents the $\{100\}$ surfaces of galena in good agreement with the SEM-EDS observations (Figure 2). One layer of the cluster was allowed to relax while the edge atoms on that layer were fixed in order to minimize edge effects that are inherent to the cluster size [46]. For the aim at calculating energetics of adsorption reactions occurring in aqueous phases, hydration was simulated by imposing the solute in a cavity within the solvent reaction field (SCRF) based on a PCM (Polarizable Continuum Model [47]) solvation model.

The adsorption Gibbs free energy is calculated from the computed Gibbs free energies of the chemical species $(X)$, the galena slab and the species adsorbed on the slab $(\mathrm{PbS} \equiv \mathrm{X})$ as described in Equation (1):

$$
\Delta \mathrm{G}_{\mathrm{ads}}^{\mathrm{X}}=\mathrm{G}(\mathrm{PbS} \equiv \mathrm{X})-\mathrm{G}(\mathrm{PbS})-\mathrm{G}(\mathrm{X}) .
$$

In Equation (1), Gibbs free energies are obtained by adding vibrational contributions ( $c_{\mathrm{p}} T$ to obtain the enthalpy and $-T \Delta S$ to include vibrational entropy). These contributions were obtained from frequency calculations on the optimized structure) to the molecular/electronic energy. Entropy changes due to hydration were included in the PCM solvation model.

\section{Results}

$\mathrm{CV}$ measures current as a function of electrochemical potential and was used here to characterize redox transformations between species with different Se oxidation states as mediated by the galena powder in the working electrode (Section 3.1). Resulting electrochemical signals were used to evaluate reduction potentials of possible redox pairs and the amounts of species changing their oxidation state within a given reduction or oxidation peak.

\subsection{Cyclic Voltammetry of Galena with and without Se(IV)}

$\mathrm{CV}$ was performed in the scan range of -0.65 to $+0.3 \mathrm{~V}$ using the galena PME in the absence of Se to establish any voltammetric signatures contributed by reactions involving the Pt and galena electrode materials (Figure 3a). In the absence of Se, the PME with galena present in the cavity exhibits 
a cathodic peak at $-440 \mathrm{mV}$ (labeled $\mathrm{C}_{\mathbf{0}}$ in Figure 3a). This peak is likely indicative of the reduction of oxidized surface elemental $\mathrm{S}$ via the following reaction taken from [48-50]:

$$
\mathrm{S}^{0}+2 \mathrm{H}^{+}+2 \mathrm{e}^{-} \rightarrow \mathrm{H}_{2} \mathrm{~S}
$$

$\mathrm{CV}$ performed in the scan range of -0.65 to $+0.3 \mathrm{~V}$ using the galena PME and Se(IV) (added as $\mathrm{Na}_{2} \mathrm{SeO}_{3}$ ) present in solution exhibited three anodic peaks and three cathodic peaks denoted $\mathbf{A}_{\mathbf{1}}$ to $\mathbf{A}_{3}$ and $\mathbf{C}_{\mathbf{1}}$ to $\mathbf{C}_{\mathbf{3}}$ (Figure 3a). The observation of peaks $\mathbf{A}_{\mathbf{1}}$ to $\mathbf{A}_{\mathbf{3}}$ and $\mathbf{C}_{\mathbf{1}}$ to $\mathbf{C}_{\mathbf{3}}$ in the scan with Se(IV) present in solution and their clear distinction from the features of the scan performed in the absence of Se attributes these peaks to Se redox reactions. The contribution of $\mathrm{Pt}$ to the total electrochemical signal can be considered minute because the galena component of the PME produces electrical signals of current one order of magnitude greater than that of the empty PME (Figure 3a).
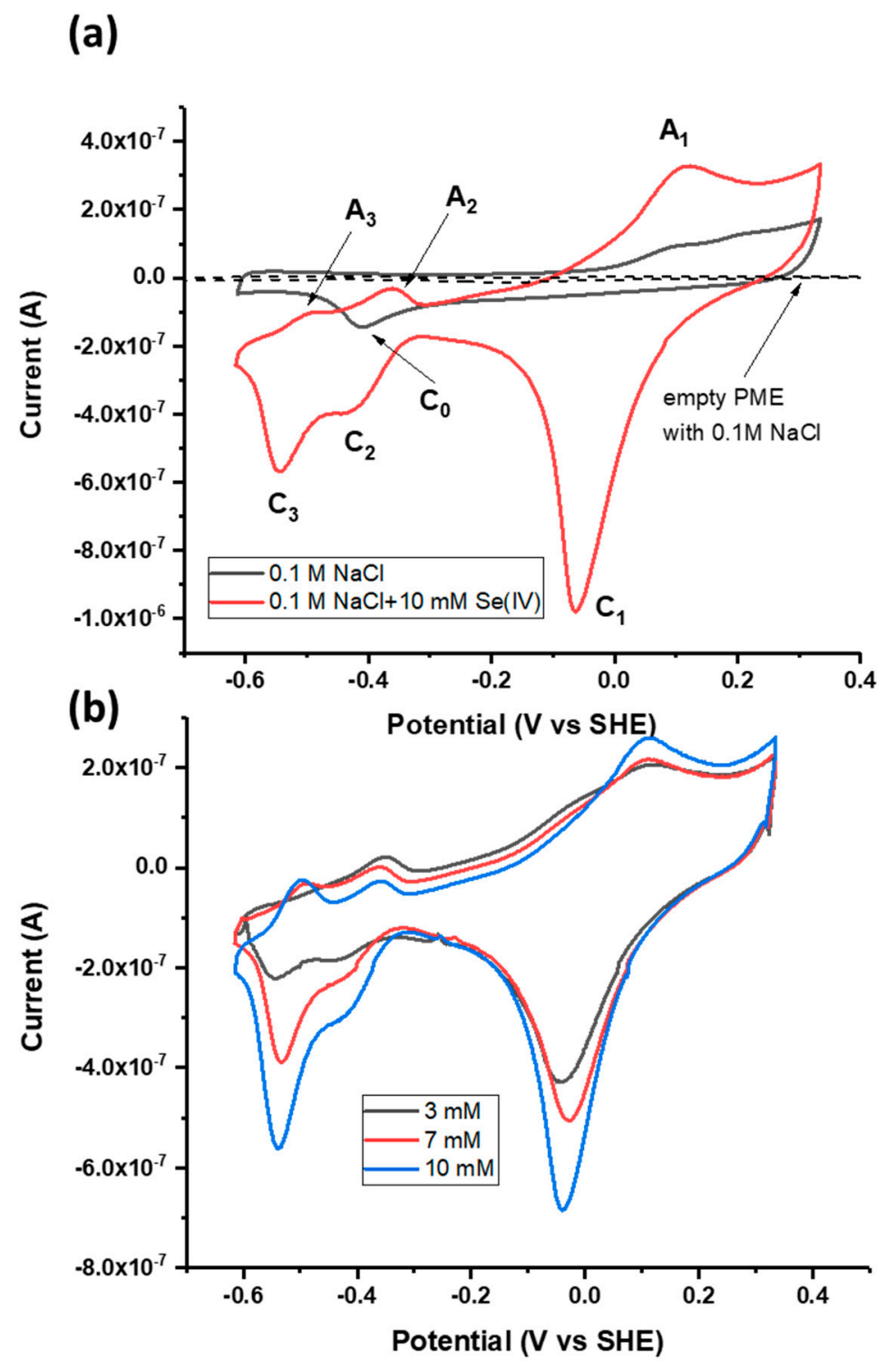

Figure 3. (a) Cyclic voltammograms of the powder microelectrode (PME) with no galena powder packed in the cavity scanned in $0.1 \mathrm{M} \mathrm{NaCl} \mathrm{pH} \mathrm{4.6,} \mathrm{the} \mathrm{PME} \mathrm{with} \mathrm{galena} \mathrm{powder} \mathrm{packed} \mathrm{in} \mathrm{the} \mathrm{cavity}$ scanned in $0.1 \mathrm{M} \mathrm{NaCl} \mathrm{pH} \mathrm{4.6,} \mathrm{and} \mathrm{the} \mathrm{PME} \mathrm{packed} \mathrm{with} \mathrm{galena} \mathrm{powder} \mathrm{scanned} \mathrm{in} 0.1 \mathrm{M} \mathrm{NaCl}+$ $10 \mathrm{mM} \mathrm{Na}_{2} \mathrm{SeO}_{3} \mathrm{pH}$ 4.6. (b) Cyclic voltammograms of galena in $0.1 \mathrm{M} \mathrm{NaCl} \mathrm{pH} 4.6$ with varying concentrations of Se(IV) (see inset). For both (a) and (b), scans were initiated from the OCP in the positive direction at $50 \mathrm{mV} / \mathrm{s}$. The final (20th) cycle of each scan is displayed. 
Association of these $\mathrm{CV}$ peaks with Se redox reactions was also substantiated by the fact that the reduction peaks $C_{1}, C_{2}$, and $C_{3}$ increase in current magnitude with increasing $\mathrm{Se}(\mathrm{IV})$ concentration (Figure $3 \mathrm{~b}$ ). While the peak current of $\mathbf{A}_{\mathbf{1}}$ increased with Se concentration, anodic peaks $\mathbf{A}_{\mathbf{2}}$ and $\mathbf{A}_{3}$ showed negative current with varying Se concentration but do not necessarily increase with the concentration. One possible reason is that Se reduction is dominant over negative potential ranges and decreases overall current even upon anodic scans below $0.0 \mathrm{~V}$. Upon the measurement using the galena PME, the intersection between the anodic scans with and without Se(IV) occurs at about 0 to $-0.1 \mathrm{~V}$ (Figure $3 \mathrm{a}, \mathrm{b}$ ) where there is transition between reductive and oxidative processes involving Se(IV) and its reduced products. Similar observations on anodic scans leading to negative current are also reported from studies regarding Se reduction measured using Au electrodes [19,51].

It should be noted that peaks $\mathbf{A}_{2}, \mathbf{A}_{3}, \mathbf{C}_{2}$ and $\mathbf{C}_{3}$ were not attributed to the hydrogen $(\mathrm{H})$ evolution on $\mathrm{Pt}$ (or galena), i.e., the redox transformation between $\mathrm{H}_{\text {and }} \mathrm{H}^{+}$and their adsorption/desorption. Typical $\mathrm{CV}$ patterns of this one-electron transfer process showed near chemical reversibility (i.e., comparable areas of cathodic and anodic peaks) and separation of the corresponding peaks is as small as $59 \mathrm{mV}$ [52] which was not the case for the current-potential region involving $\mathbf{A}_{2}, \mathbf{A}_{\mathbf{3}}, \mathbf{C}_{\mathbf{2}}$ and $\mathbf{C}_{\mathbf{3}}$. Furthermore while these reactions are commonly observed from measurements in strong acid solutions, the voltammetric signature from $\mathrm{H}$ evolution is unlikely to contribute to an observable degree under the current experimental conditions where the concentration of Se is higher than that of protons by a factor of two or three. Given the same $\mathrm{pH}$ of 4.6 in each case, any H evolution occurring in scans performed in the presence of Se would have been observed in those in the absence of Se.

While galena can, as a redox catalyst, influence the kinetics of the reaction, the formation of bonding of different Se species with the galena surface can lead to a variation on the peak position [46]. We address such energetic contribution of adsorption using quantum-mechanical calculations (Section 3.3). It is important to note that in this electrochemical system, the ultimate source and sink for electrons is the electrode, i.e., the potentiostat with electrons being transferred by the platinum wire and galena powder, and not, e.g., the $S 3 p$ orbitals of galena.

\subsection{Peak Pairing and Assignment to Se Redox Transformations}

Prior to peak quantification and reaction assignment, it was necessary to pair oxidation and reduction peaks to specific Se redox transformation mediated by galena. To aid pairing the Se-related peaks, linear sweep voltammetry (LSV) was used to limit scans to a single direction rather than including a reverse scan such as with $\mathrm{CV}$. This allowed us to examine individual oxidation and reduction processes observed in narrow scan ranges.

Successive linear sweeps were performed in the negative-going (i.e., cathodic) and positive-going (anodic) direction over a potential range from +300 to $-100 \mathrm{mV}$. In separate scans on fresh galena powder, growth of $\mathbf{C}_{\mathbf{1}}$ was observed with successive cathodic sweeps (Figure $4 a$ ) while no noticeable feature was observed with anodic sweeps performed over the same potential range. However, the growth of $\mathbf{A}_{\mathbf{1}}$ is observed with anodic sweeps scanned after successive cathodic sweeps producing $\mathbf{C}_{\mathbf{1}}$ are performed on the same galena powder (Figure $4 \mathbf{b}$ ). These results indicate that $\mathbf{A}_{\mathbf{1}}$ involved the reversible reaction of $\mathbf{C}_{\mathbf{1}}$ constituting a redox couple (denoted with $\mathbf{C}_{\mathbf{1}} / \mathbf{A}_{\mathbf{1}}$ ). The peak potentials of $\mathbf{A}_{\mathbf{1}} / \mathbf{C}_{\mathbf{1}}$ were observed at $+120 /-60 \mathrm{mV}$ (Figure 3a). Figure 5 shows cathodic linear sweeps over a potential range from $-265 \mathrm{mV}$ to $-615 \mathrm{mV}$. The measurements exhibited growth of one broad, large peak with the first few sweeps which evolved into peak $C_{2}$ and $C_{3}$ in later sweeps. Peak $A_{2}$ and $A_{3}$ were assigned to the reverse reaction of $C_{2}$ and $C_{3}$ constituting redox couples $C_{2} / A_{2}$ and $C_{3} / A_{3}$ due to their later emergences upon anodic scans with progressive $C V$ cycling. The peak potentials of $\mathbf{A}_{\mathbf{2}} / \mathbf{C}_{\mathbf{2}}$ are observed at $-360 /-440 \mathrm{mV}$, and of $\mathbf{A}_{3} / \mathbf{C}_{3}$ at $-500 /-540 \mathrm{mV}$ (Figure $3 \mathrm{a}$ ). 



Figure 4. (a) Successive negative-going linear sweeps of galena in $10 \mathrm{mM} \mathrm{Na}_{2} \mathrm{SeO}_{3}+0.1 \mathrm{M} \mathrm{NaCl} \mathrm{pH}$ 4.6 at $50 \mathrm{mV} / \mathrm{s}$. (b) Positive-going linear sweeps of separate galena powders in $10 \mathrm{mM} \mathrm{Na}_{2} \mathrm{SeO}_{3}+$ $0.1 \mathrm{M} \mathrm{NaCl} \mathrm{pH} 4.6$ at $50 \mathrm{mV} / \mathrm{s}$ performed without prior voltammetry (black) and after the cathodic scans shown in (a) were performed (red) whereupon $\mathbf{A}_{\mathbf{1}}$ emerges. The emergence of $\mathbf{A}_{\mathbf{1}}$ only after $\mathbf{C}_{\mathbf{1}}$ is produced indicates that it is the reverse reaction of $\mathbf{C}_{\mathbf{1}}$.

Given peak potentials of a redox couple, $\mathrm{E}_{\text {mid }}$ can be defined allowing a first-order approximation of a reduction potential. For peak assignment, the observed $\mathrm{E}_{\text {mid }}$ is compared with the equilibrium reduction potentials of Se redox pairs. The Nernst equation defines the deviation of the equilibrium reduction potential from the standard reduction potential as a function of $\mathrm{pH}$ and the concentrations of the reductants and the oxidants:

$$
\mathrm{E}=\mathrm{E}^{0}-\frac{59 \mathrm{mV}}{\mathrm{n}} \cdot \log \frac{\prod a_{\text {products }}}{\prod a_{\text {reactants }}},
$$

where $\mathrm{E}$ is the equilibrium reduction potential, $\mathrm{E}^{0}$ is the standard reduction potential, $\mathrm{n}$ is the number of electrons transferred, dictated by the reaction stoichiometry, and this ratio is multiplied by the log of the reaction quotient.

The Nernst equations and the standard reduction potentials of Se redox pairs relevant to the experimental conditions of this study are summarized in Table 1. In Table 2, the equilibrium reduction potentials are estimated for a solution $\mathrm{pH}$ of 4.6 and the presumed concentrations of relevant selenium species. Since $\mathrm{HSeO}_{3}{ }^{-}$is the most dominant $\mathrm{Se}(\mathrm{IV})$ species at $\mathrm{pH} 4.6\left(\mathrm{pk}_{\mathrm{a} 1}=2.7\right.$ and $\mathrm{pk}_{\mathrm{a} 2}=8$ for $\left.\mathrm{H}_{2} \mathrm{SeO}_{3}\right)$, it is reasonable to assume that the initial Se(IV) concentration $(0.01 \mathrm{M})$ is approximately equal to $\left[\mathrm{HSeO}_{3}{ }^{-}\right]$. In the bulk solution $(50 \mathrm{~mL})$, the concentration of other Se species would be minute 
because they can only be produced from the Se(IV) redox reactions occurring by means of the galena PME. One constraint on the $\mathrm{Se}(-\mathrm{II})$ species is considered that the ratio of $\left[\mathrm{HSe}^{-}\right]$to $\left[\mathrm{H}_{2} \mathrm{Se}\right]$ is 5 at $\mathrm{pH} 4.6\left(\mathrm{pk}_{\mathrm{a} 1}=3.9\right.$ for $\left.\mathrm{H}_{2} \mathrm{Se}\right)$. The equilibrium reduction potentials in Table 2 are calculated where $\left[\mathrm{HSe}^{-}\right]=5 \times 10^{-6} \mathrm{M},\left[\mathrm{H}_{2} \mathrm{Se}\right]=10^{-6} \mathrm{M}$, and $\left[\mathrm{SeO}_{4}{ }^{2-}\right]=10^{-6} \mathrm{M}$.

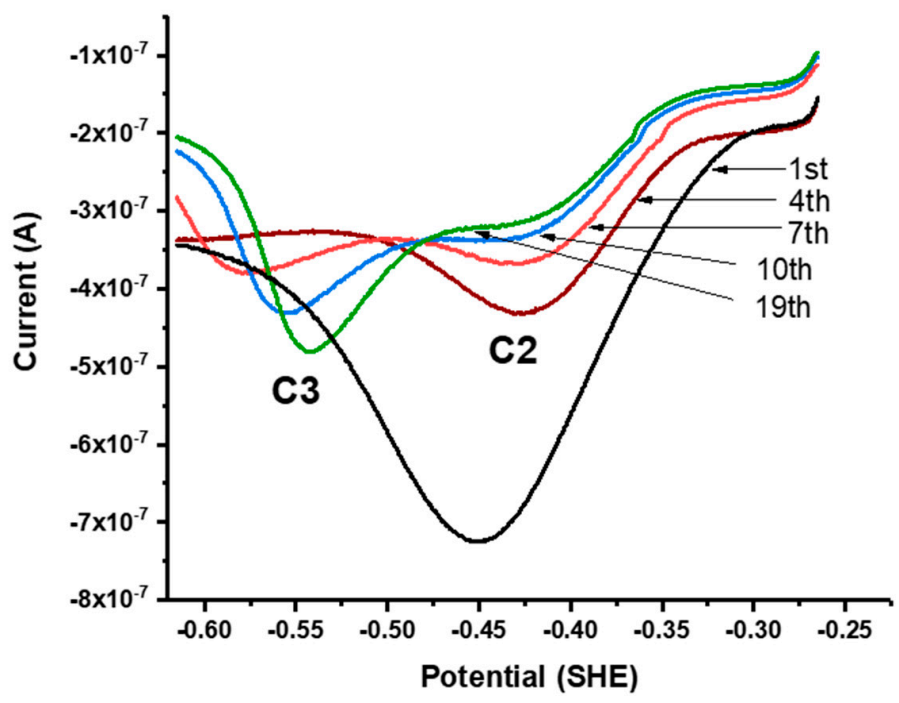

Figure 5. Successive linear sweeps of galena in $10 \mathrm{mM} \mathrm{Na}_{2} \mathrm{SeO}_{3}+0.1 \mathrm{M} \mathrm{NaCl} \mathrm{pH} \mathrm{4.6.} \mathrm{Sweeps} \mathrm{were}$ scanned from $-265 \mathrm{mV}$ to $-615 \mathrm{mV}$ at $50 \mathrm{mV} / \mathrm{s}$. The measurements exhibit growth of one broad, large peak with the first few sweeps, which evolves into peak $\mathbf{C}_{2}$ and $\mathbf{C}_{3}$ in later sweeps.

Table 1. Redox potential equations and standard redox potentials for possible redox reactions of Se(IV) as a function of $\mathrm{pH}$ and the concentrations of oxidants and reductants.

\begin{tabular}{|c|c|}
\hline Redox Reaction & Standard Redox Potential * (vs. SHE) \\
\hline $\begin{array}{l}\text { (I) } \mathrm{HSeO}_{3}{ }^{-}+5 \mathrm{H}^{+}+4 \mathrm{e}^{-}=\mathrm{Se}(\mathrm{s})+3 \mathrm{H}_{2} \mathrm{O} \\
\mathrm{E}=0.78-0.074 \mathrm{pH}+0.015 \log \left[\mathrm{HSeO}_{3}{ }^{-}\right]\end{array}$ & $\mathrm{E}^{0}=0.78 \mathrm{~V}$ \\
\hline $\begin{array}{c}\text { (II) } \mathrm{HSeO}_{3}^{-}+6 \mathrm{H}^{+}+6 \mathrm{e}^{-}=\mathrm{H}_{2} \mathrm{Se}+3 \mathrm{H}_{2} \mathrm{O} \\
\mathrm{E}=0.386-0.059 \mathrm{pH}+0.010 \log \left[\mathrm{HSeO}_{3}^{-}\right] /\left[\mathrm{H}_{2} \mathrm{Se}\right]\end{array}$ & $\mathrm{E}^{0}=0.386$ \\
\hline $\begin{array}{c}\text { (III) } \mathrm{HSeO}_{3}^{-}+6 \mathrm{H}^{+}+6 \mathrm{e}^{-}=\mathrm{HSe}^{-}+3 \mathrm{H}_{2} \mathrm{O} \\
\mathrm{E}=0.35-0.059 \mathrm{pH}+0.010 \log \left[\mathrm{HSeO}_{3}^{-}\right] /\left[\mathrm{HSe}^{-}\right]\end{array}$ & $\mathrm{E}^{0}=0.35$ \\
\hline $\begin{array}{c}(\mathrm{IV}) \mathrm{Se}(\mathrm{s})+2 \mathrm{H}^{+}+2 \mathrm{e}^{-}=\mathrm{H}_{2} \mathrm{Se} \\
\mathrm{E}=-0.4-0.059 \mathrm{pH}-0.030 \log \left[\mathrm{H}_{2} \mathrm{Se}\right]\end{array}$ & $\mathrm{E}^{0}=-0.4$ \\
\hline $\begin{array}{c}\text { (V) Se(s) }+\mathrm{H}^{+}+2 \mathrm{e}^{-}=\mathrm{HSe}^{-} \\
\mathrm{E}=-0.51-0.030 \mathrm{pH}-0.030 \log \left[\mathrm{HSe}^{-}\right]\end{array}$ & $E^{0}=-0.51$ \\
\hline $\begin{array}{c}\text { (IV) } \mathrm{SeO}_{4}{ }^{2-}+3 \mathrm{H}^{+}+2 \mathrm{e}^{-}=\mathrm{HSeO}_{3}{ }^{-}+\mathrm{H}_{2} \mathrm{O} \\
\mathrm{E}=1.08-0.089 \mathrm{pH}+0.030 \log \left[\mathrm{SeO}_{4}^{2-}\right] /\left[\mathrm{HSeO}_{3}{ }^{-}\right]\end{array}$ & $\mathrm{E}^{0}=1.08$ \\
\hline $\begin{array}{c}\text { (VII) } \mathrm{SeO}_{4}{ }^{2-}+8 \mathrm{H}^{+}+6 \mathrm{e}^{-}=\mathrm{Se}(\mathrm{s})+4 \mathrm{H}_{2} \mathrm{O} \\
\mathrm{E}=1.86-0.079 \mathrm{pH}+0.010 \log \left[\mathrm{SeO}_{4}{ }^{2-}\right]\end{array}$ & $\mathrm{E}^{0}=1.86$ \\
\hline $\begin{array}{c}\text { (VIII) } \mathrm{SeO}_{4}^{2-}+9 \mathrm{H}^{+}+8 \mathrm{e}^{-}=\mathrm{HSe}^{-}+4 \mathrm{H}_{2} \mathrm{O} \\
\mathrm{E}=1.43-0.066 \mathrm{pH}+0.007 \log \left[\mathrm{SeO}_{4}^{2-}\right] /\left[\mathrm{HSe}^{-}\right]\end{array}$ & $\mathrm{E}^{0}=1.43$ \\
\hline
\end{tabular}

For the $\mathbf{C}_{\mathbf{1}} / \mathbf{A}_{\mathbf{1}}$ couple, $\mathrm{E}_{\text {mid }}$ was defined at $+0.03 \mathrm{~V}$ and the best agreement with the equilibrium reduction potentials (Table 2 ) is found for the redox pairs $\mathrm{HSeO}_{3}{ }^{-} / \mathrm{H}_{2} \mathrm{Se}$ and $\mathrm{HSeO}_{3}{ }^{-} / \mathrm{HSe}^{-}$. The $\mathrm{E}_{\text {mid }}$ values of $\mathbf{C}_{2} / \mathbf{A}_{2}$ and $\mathbf{C}_{3} / \mathbf{A}_{3}$ were defined at -0.4 and $-0.52 \mathrm{~V}$ which were close to the equilibrium potentials of $\mathrm{Se}(0) / \mathrm{H}_{2} \mathrm{Se}$ and $\mathrm{Se}(0) / \mathrm{HSe}^{-}$. Further specification was limited because the equilibrium potentials of these two redox pairs estimated at $\mathrm{pH} 4.6$ are nearly the same $(\approx-0.49 \mathrm{~V})$. Quantification on peak shifts caused by the different binding energies of Se species with the galena surface aids in assigning these peaks to specific redox pairs (Section 3.3). 
Table 2. Equilibrium redox potentials of Se redox transformation pairs at $\mathrm{pH} 4.5$ and those values corrected for the adsorption contributions to the redox potentials.

\begin{tabular}{|c|c|c|c|c|c|}
\hline Oxidant/Reductant Pair & $\begin{array}{l}\text { Equilibrium } \\
\text { Pot. @ } \mathrm{pH} 4.5 \text { * } \\
\text { (V) }\end{array}$ & $\begin{array}{c}\Delta \Delta \mathrm{G}_{\text {ads }} \text { Per } \mathrm{e}^{-} \\
\text {Transferred } \\
\text { (V) }\end{array}$ & $\begin{array}{c}\text { Reduction } \\
\text { Potential with } \\
\text { Correction of } \\
\Delta \Delta \mathrm{G}_{\text {ads }}(\mathrm{V})\end{array}$ & $\begin{array}{c}\text { CV Peak } \\
\text { Assign-ment }\end{array}$ & $\begin{array}{c}\text { Mid-Point } \\
\text { Potential (V) }\end{array}$ \\
\hline $\mathrm{HSeO}^{3-} / \mathrm{Se}(0)$ & 0.32 & -0.18 & 0.14 & & \\
\hline $\mathrm{HSeO}^{3-} / \mathrm{H}_{2} \mathrm{Se}$ & 0.15 & -0.17 & -0.01 & $\mathrm{C}_{1} / \mathrm{A}_{1}$ & 0.03 \\
\hline $\mathrm{HSeO}^{3-} / \mathrm{HSe}^{-}$ & 0.11 & -0.07 & 0.04 & $\mathrm{C}_{1} / \mathrm{A}_{1}$ & 0.03 \\
\hline $\mathrm{Se}(0) / \mathrm{H}_{2} \mathrm{Se}$ & -0.49 & -0.15 & -0.64 & $\mathrm{C}_{3} / \mathrm{A}_{3}$ & -0.52 \\
\hline $\mathrm{Se}(0) / \mathrm{HSe}^{-}$ & -0.49 & 0.15 & -0.34 & $\mathrm{C}_{2} / \mathrm{A}_{2}$ & -0.40 \\
\hline $\mathrm{SeO}_{4}{ }^{2-} / \mathrm{HSeO}_{3}{ }^{-}$ & 0.55 & -0.02 & 0.54 & & \\
\hline $\mathrm{SeO}_{4}^{2-} / \mathrm{Se}(0)$ & 1.44 & -0.17 & 1.27 & & \\
\hline $\mathrm{SeO}_{4}{ }^{2-} / \mathrm{HSe}^{-}$ & 1.12 & -0.05 & 1.06 & & \\
\hline
\end{tabular}

${ }^{*}$ Equilibrium potentials were calculated based on the half redox reaction equations presented in Table 1 where $\left[\mathrm{HSeO}_{3}{ }^{-}\right]=10^{-2} \mathrm{M},\left[\mathrm{HSe}^{-}\right]=10^{-5} \mathrm{M},\left[\mathrm{H}_{2} \mathrm{Se}\right]=10^{-6} \mathrm{M}$, and $\left[\mathrm{SeO}_{4}{ }^{2-}\right]=10^{-6} \mathrm{M}$.

\subsection{Adsorption of Se Species on Galena}

Adsorption is needed for a dissolved species to remain in contact with a solid surface and occurs before electrons are transferred between the electrode surface and the chemical species. Interaction between a mineral surface and a chemical species can be an important parameter in quantifying the thermodynamics of electron transfer mediated by a mineral surface in that it can cause deviation from theoretical equilibrium redox potentials within a few hundred $\mathrm{mV}$ [46,54-56]. Here, energetic contributions of adsorption to Se redox thermodynamics were calculated using the computational code, Gaussian 09. Comparison between the observed midpoint potential and the equilibrium redox potential (Section 3.2) was further explored and it was examined whether consistency between the observed and the theoretical reduction potentials is improved with correction for the adsorption contributions to the reduction potentials.

The adsorbate structures shown in Figure 6 are the most likely reaction products according to the calculations presented in this study. The bidentate mode of $\mathrm{HSeO}_{3}{ }^{-}$on galena includes the oxygen bond with surface $\mathrm{Pb}(\mathrm{Pb}-\mathrm{O}=2.4 \AA$ ) and attractive interaction between $\mathrm{H}$ and surface $\mathrm{S}$ (Figure $6 \mathrm{a}, \mathrm{b}$ ). The $\Delta \mathrm{G}_{\text {ads }}$ of $\mathrm{HSeO}_{3}{ }^{-}$, following a frequency analysis, on galena was calculated to be $-69 \mathrm{~kJ} / \mathrm{mol}$. Interaction of $\mathrm{HSe}^{-}$with the galena surface was in a monodentate mode (Figure $6 \mathrm{c}$ ). The calculated Se-Pb distance is $3.0 \AA$ and the $\Delta \mathrm{G}_{\mathrm{ads}}$ is $-30 \mathrm{~kJ} / \mathrm{mol}$. $\mathrm{H}_{2}$ Se weakly interacts with the galena surface (Se-Pb of $3.5 \AA$ ) which is indicated by the positive $\Delta \mathrm{G}_{\mathrm{ads}}(=+29 \mathrm{~kJ} / \mathrm{mol}$ ) (Figure $6 \mathrm{~d}$ ). This also indicates that reduction of $\mathrm{Se}(\mathrm{IV})$ to $\mathrm{H}_{2} \mathrm{Se}$, especially at $\mathrm{pH}$ values more acidic than the experimental one of 4.6, would lead to the release of $\mathrm{H}_{2} \mathrm{Se}$ into solution while HSe is calculated to stay adsorbed to the galena surface.

The energetic contribution of adsorption on galena to redox thermodynamics was evaluated from calculating the difference in Gibbs free energy between the redox half reaction for dissolved species (Equation (4)) and one for adsorbed species (Equation (5)). This difference (Equation (6)) was equivalent to the reaction involving the oxidant adsorbed on galena $(\mathrm{PbS} \equiv \mathrm{Ox})$ and the dissolved reductant (Red) as reactants and the adsorbed galena $(\mathrm{PbS} \equiv \operatorname{Red})$ and the dissolved oxidant $(\mathrm{Ox})$ as products (Figure 7). In turn, this reaction equation corresponds to the subtraction of the oxidant adsorption equation (Equation (7)) from the reductant adsorption equation (Equation (8)).

$$
\begin{gathered}
\mathrm{Ox}+\mathrm{ne}^{-} \leftrightarrow \mathrm{Red} \\
\mathrm{PbS} \equiv \mathrm{Ox}+\mathrm{ne}^{-} \leftrightarrow \mathrm{PbS} \equiv \operatorname{Red} \\
\mathrm{PbS} \equiv \mathrm{Ox}+\operatorname{Red} \leftrightarrow \mathrm{PbS} \equiv \operatorname{Red}+\mathrm{Ox} \\
\mathrm{PbS}+\mathrm{Ox} \leftrightarrow \mathrm{PbS} \equiv \mathrm{Ox} \\
\mathrm{PbS}+\operatorname{Red} \leftrightarrow \mathrm{PbS} \equiv \operatorname{Red}
\end{gathered}
$$




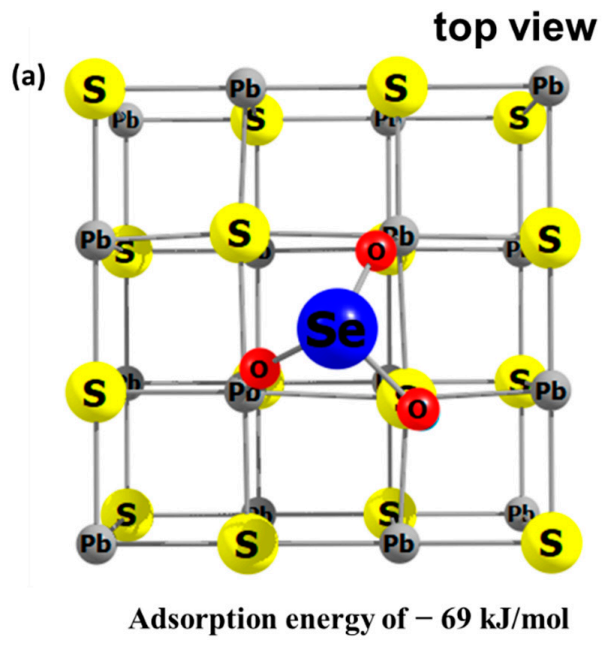

(c)



$\Delta \mathbf{G}_{\text {ads }}$ of $-30 \mathrm{~kJ} / \mathrm{mol}$



(d)

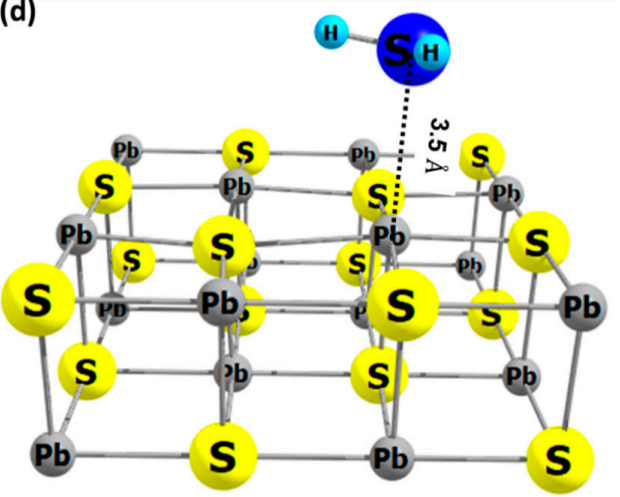

$\Delta \mathbf{G}_{\mathrm{ads}}$ of $+29 \mathrm{~kJ} / \mathrm{mol}$

Figure 6. The energy optimized geometry of adsorbate on galana (100) surface, (a,b) $\mathrm{HSeO}_{3}{ }^{-}(\mathbf{c}) \mathrm{HSe}^{-}$ and (d) $\mathrm{H}_{2} \mathrm{Se}$, with their calculated adsorption Gibbs free energies. In this study, the redox transformation of Se is mediated by galena and therefore adsorption of the Se species is an important contribution to the redox transformation.

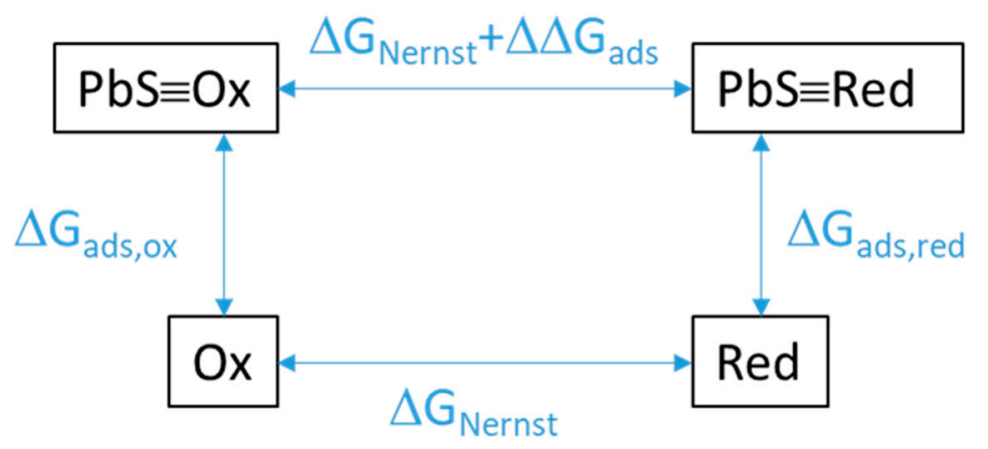

Figure 7. Schematic of the energy shift of a redox reaction as a result of the redox species being adsorbed $(\mathrm{PbS} \equiv \mathrm{Ox}, \mathrm{Pbs} \equiv \mathrm{Red})$ rather than being in solution (Ox, Red). $\Delta \Delta \mathrm{G}_{\mathrm{ads}}$ is the difference in the Gibbs free energies of adsorption of the oxidized vs. reduced species. $\Delta \mathrm{G}_{\mathrm{Nernst}}$ is the expected energy of reaction from the Nernst equation by multiplying the Nernst potential $\mathrm{E}$ by $-\mathrm{nF}$.

The change in redox potential by adsorption $(\Delta \mathrm{V})$ is related to the difference in the adsorption Gibbs free energies as described in Figure 7 and Equation (9):

$$
\Delta\left(\Delta \mathrm{G}_{\mathrm{ads}}\right)=\Delta \mathrm{G}_{\mathrm{ads}}^{\mathrm{Red}}-\Delta \mathrm{G}_{\mathrm{ads}}^{\mathrm{Ox}}=-\mathrm{nF} \Delta \mathrm{V} .
$$


Overall, the computed contribution of adsorption to redox thermodynamics ranges from -0.05 to $-0.18 \mathrm{~V}$ which indicates the shift of the redox potential position to more negative values than the theoretically derived equilibrium redox potentials (Table 2). The midpoint potentials of Se-attributed redox transformations measured from galena CVs (Sections 3.1 and 3.2) are in good agreement with reduction potentials corrected for the adsorption contributions and support peak assignment: the observed midpoint potential of $\mathbf{C}_{\mathbf{1}} / \mathbf{A}_{\mathbf{1}}(=0.03 \mathrm{~V})$ was very close to the corrected redox potentials for the redox couples of $\mathrm{HSeO}_{3}{ }^{-} / \mathrm{H}_{2} \mathrm{Se}(-0.01 \mathrm{~V})$ and $\mathrm{HSeO}_{3}{ }^{-} / \mathrm{HSe}^{-}(0.05 \mathrm{~V})$; the midpoint potential of $\mathbf{C}_{2} / \mathbf{A}_{2}(-0.40 \mathrm{~V})$ is comparable to the corrected reduction potential of $\mathrm{Se}(0) / \mathrm{HSe}^{-}(-0.34 \mathrm{~V})$ while that of $\mathrm{C}_{3} / \mathrm{A}_{3}(-0.52 \mathrm{~V})$ is close to the corrected reduction potential of $\mathrm{Se}(0) / \mathrm{H}_{2} \mathrm{Se}(-0.64 \mathrm{~V})$.

To sum up, based on evaluation of equilibrium reduction potentials (Section 3.2) and the adsorption contribution to the selenium redox thermodynamics on galena (Section 3.3), the observed CV peaks were assigned to individual redox pairs and the intimate growth of peak $\mathbf{C}_{2}$ and $\mathbf{C}_{3}$ observed during the linear cathodic scans (Figure 5) was attributed to the reduction of $\mathrm{Se}(0)$ to $\mathrm{Se}(-\mathrm{II})$ in association with selenide speciation.

\subsection{XPS Measurements}

XPS spectra were obtained to identify the products of Se redox transformation mediated by galena. For this purpose, bulk galena electrodes were polarized for $30 \mathrm{~min}$ in solution containing $10 \mathrm{mM}$ $\mathrm{Na}_{2} \mathrm{SeO}_{3}+0.1 \mathrm{M} \mathrm{NaCl}$ adjusted to $\mathrm{pH}$ 4.6. The potential was held at two potential values $-0.125 \mathrm{~V}$ and $-0.49 \mathrm{~V}$ corresponding to approximate peak positions of $\mathbf{C}_{\mathbf{1}}$ and $\mathbf{C}_{\mathbf{2}}$ observed with cyclic voltammetry.

Core scans for the Se $3 \mathrm{~d}$ peak are presented in Figure 8. Galena polarized at $-0.125 \mathrm{~V}$ yields peaks that indicate the presence of Se(IV) and Se(0) with 3d 5/2 spin-orbit split peaks located at 58.4 and $55.0 \mathrm{eV}$, respectively (Figure $8 \mathrm{a}$ and Table 3). The peak observed at $55.0 \mathrm{eV}$ was attributed to $\mathrm{Se}(0)$ which is in agreement with the standard value of $55.2 \mathrm{eV}$ and within the range of 54.8 to $56.3 \mathrm{eV}[32,57]$ commonly reported for Se(0). The proportion of Se oxidation states are $51 \% / 49 \%$ for $\mathrm{Se}(0) / \mathrm{Se}(\mathrm{IV})$. From the galena electrode polarized at $-0.49 \mathrm{~V}$, the Se core scans reveal three peaks attributed to $\mathrm{Se}(\mathrm{IV})$ at $58.3 \mathrm{eV}$, Se(0) at $54.4 \mathrm{eV}$ and $\mathrm{Se}(-\mathrm{II})$ species at $52.8 \mathrm{eV}$ (Figure $8 \mathrm{~b}$ and Table 3). Formation of a red film on the galena electrode was macroscopically observable after it was held at a potential of $-0.49 \mathrm{~V}$ for $30 \mathrm{~min}$ which is evidence of $\mathrm{Se}(0)$ as reported from previous studies $[30,58,59]$. The peak at $52.8 \mathrm{eV}$ indicates the formation of $\mathrm{Se}(-\mathrm{II})$ species such as $\mathrm{HSe}^{-}$and $\mathrm{H}_{2} \mathrm{Se}$ in good agreement with the peak assignment of peak $C_{2}$. This Se $3 d 5 / 2$ peak is within a range of binding energies typically reported for Se(-II) compounds [32]. The relative proportions of Se oxidation states are $29 \% / 32 \% / 39 \%$ for $\mathrm{Se}(-\mathrm{II}) / \mathrm{Se}(0) / \mathrm{Se}(\mathrm{IV})$, respectively.

Table 3. Se $3 \mathrm{~d}$ spectra of the galena electrodes polarized for 30 minutes at -125 , and $-490 \mathrm{mV}$. Relative percentages of species with different Se oxidation states for the redox conditions. The reaction solution was prepared using $10 \mathrm{mM} \mathrm{Na}_{2} \mathrm{SeO}_{3}$ and $0.1 \mathrm{M} \mathrm{NaCl}$ at $\mathrm{pH}$ 4.6.

\begin{tabular}{|c|c|c|c|c|c|c|}
\hline \multirow{2}{*}{$\begin{array}{l}\text { XPS Binding Energy of } \\
\text { Se Species }\end{array}$} & \multicolumn{2}{|c|}{ Se(IV) } & \multicolumn{2}{|c|}{$\operatorname{Se}(0)$} & \multicolumn{2}{|c|}{ Se(-II) } \\
\hline & $3 d 5 / 2(e V)$ & $3 \mathrm{~d} 3 / 2(\mathrm{eV})$ & $3 d 5 / 2(e V)$ & $3 \mathrm{~d} 3 / 2(\mathrm{eV})$ & $3 d 5 / 2(e V)$ & $3 \mathrm{~d} 3 / 2(\mathrm{eV})$ \\
\hline Polarization @ $-125 \mathrm{mV}$ & 58.5 & 59.2 & 55 & 55.9 & - & - \\
\hline Relative proportion & \multicolumn{2}{|c|}{$49 \%$} & \multicolumn{2}{|c|}{$51 \%$} & \multicolumn{2}{|c|}{ - } \\
\hline Polarization @ $-490 \mathrm{mV}$ & 58.2 & 59.1 & 54.4 & 55.3 & 52.5 & 53.3 \\
\hline Relative proportion & \multicolumn{2}{|c|}{$39 \%$} & \multicolumn{2}{|c|}{$32 \%$} & \multicolumn{2}{|c|}{$29 \%$} \\
\hline Black selenium & ـ & ـ & 55.1 & 55.9 & _ & - \\
\hline $\mathrm{Na}_{2} \mathrm{SeO}_{3}$ & 58.3 & 59.4 & - & - & - & - \\
\hline
\end{tabular}



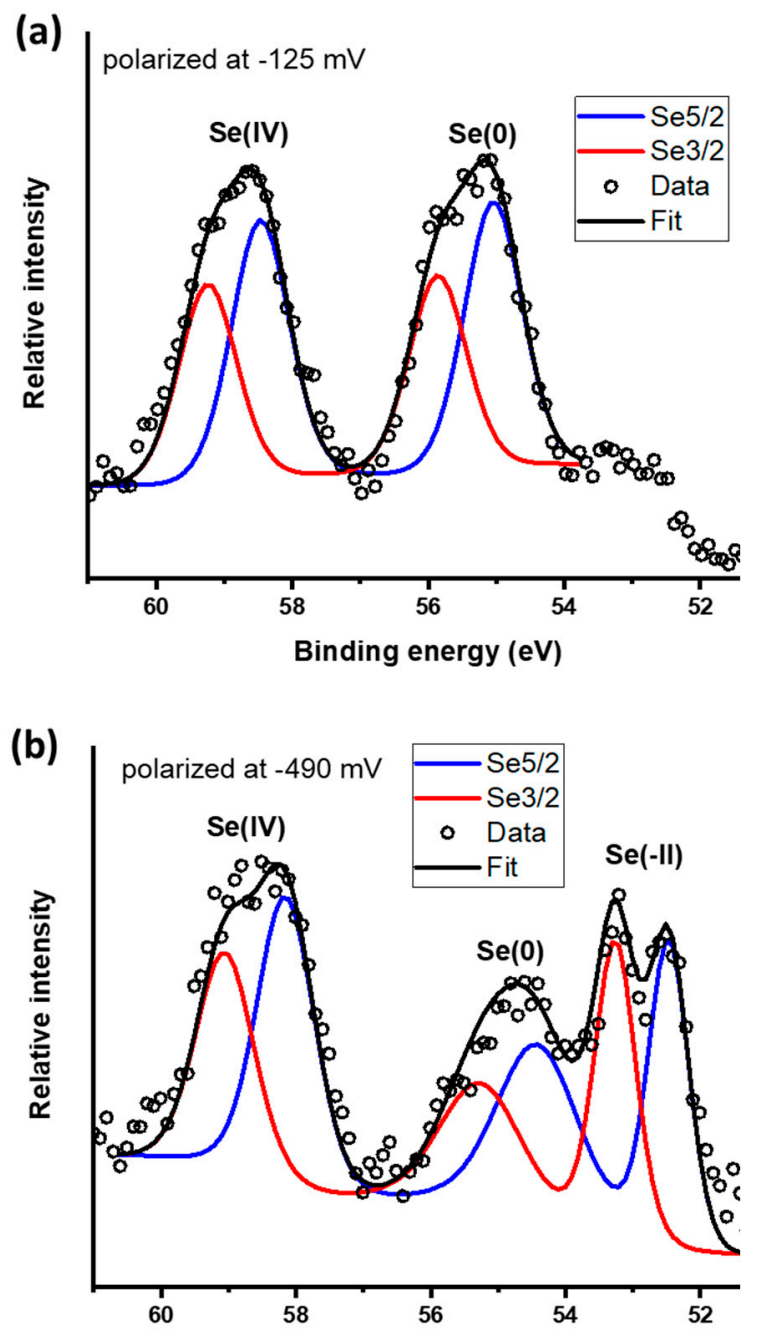

Figure 8. X-ray photoelectron spectroscopy (XPS) core scans for Se 3d spectra on the galena electrodes potential held at (a) $-125 \mathrm{mV}$ and (b) $-490 \mathrm{mV}$.

\section{Discussion}

\subsection{Possible Forms and Behavior of Products of Se Reduction Mediated by Galena}

The electrochemical and spectroscopic data presented in this study reveal the formation of $\operatorname{Se}(0)$ at potentials below $+30 \mathrm{mV}$ (i.e., the mid potential of $\mathbf{C}_{\mathbf{1}} / \mathbf{A}_{\mathbf{1}}$ ) and of protonated $\mathrm{Se}(-\mathrm{II})$ below $-400 \mathrm{mV}$. Here, possible forms and behavior of $\mathrm{Se}(0)$ and $\mathrm{Se}(-\mathrm{II})$ at the galena-solution interface are discussed.

The binding energies of $\mathrm{Se}(0)$ shown on the XPS spectra of the galena surfaces polarized at $-0.125 \mathrm{~V}$ and $-490 \mathrm{~V}$ deviate by $\sim 0.6 \mathrm{eV}$ which indicates that $\mathrm{Se}(0)$ produced at these negative potentials are likely to be in different forms. Se(0) occurs in various forms including red monoclinic $\mathrm{Se}(0)$ and grey (or black) trigonal Se(0) [58-60]. The $\mathrm{Se}^{0}$ spin-orbit splits for the $-0.125 \mathrm{~V}$ sample are very close to those for grey $\mathrm{Se}(0)$ (Table 3). Additionally, a red film characteristic of Se(0) formation was observed on galena bulk electrodes after a potential hold at $-490 \mathrm{mV}$ for 30 minutes (Section 3.4). These observations suggest possible reduction potential-dependent regions of stability for a particular type of $\mathrm{Se}(0)$ in agreement with Espinosa et al. [61] reporting red $\mathrm{Se}^{0}$ formation on carbon paste electrodes only if potentials were scanned below $-0.2 \mathrm{~V}$. This possibility is also accordant with X-ray absorption spectroscopic (XAS) data reported by Scheinost and Chalet [62] reporting grey and red $\mathrm{Se}(0)$ as products of $\mathrm{Se}(\mathrm{IV})$ reduction in the presence of Fe-bearing minerals.

A red film was observed on galena bulk electrodes after a potential hold at $-490 \mathrm{mV}$ for 30 minutes (Section 3.4) which is characteristic of the Se(0) formation. A number of electrochemical studies have 
attributed the formation of Se(0) to the comproportionation between Se(IV) and Se(-II) species [25,28,61]. When $\mathrm{Se}\left(-\mathrm{II}\right.$ ) species ( $\mathrm{HSe}^{-}$and $\mathrm{H}_{2} \mathrm{Se}$ ) are produced at $\mathrm{C}_{\mathbf{1}}$ to $\mathrm{C}_{3}$, subsequent comproportionation reactions can proceed in Se(IV)-containing solutions (Equations (10) and (11)):

$$
\begin{gathered}
\mathrm{HSeO}_{3}{ }^{-}+2 \mathrm{HSe}^{-}+3 \mathrm{H}^{+} \rightarrow 3 \mathrm{Se}^{0}+3 \mathrm{H}_{2} \mathrm{O} \\
\mathrm{HSeO}_{3}{ }^{-}+2 \mathrm{H}_{2} \mathrm{Se}+\mathrm{H}^{+} \rightarrow 3 \mathrm{Se}^{0}+3 \mathrm{H}_{2} \mathrm{O}
\end{gathered}
$$

By comparing the charge (in Coulombs) passed by the reverse peak $\left(C_{R}\right)$ to the forward peak $\left(C_{F}\right)$ of a redox couple, a charge ratio is obtained where $C_{R} / C_{F}=1$ for an ideal, Nernstian reaction. Electron charges of a given peak are obtained by integrating the current of a peak over the applied voltage and dividing the result by the scan rate. As of the final cycle of Figure $3 a$, the $\mathbf{C}_{\mathbf{1}} / \mathbf{A}_{\mathbf{1}}, \mathbf{C}_{\mathbf{2}} / \mathbf{A}_{\mathbf{2}}$, and $\mathbf{C}_{\mathbf{3}} / \mathbf{A}_{\mathbf{3}}$ couples have charge ratios of $\sim 0.27, \sim 0.44, \sim 0.14$, respectively. The $C_{R} / C_{F}<1$ for all three couples indicates that the anodic scanning is capable of reoxidizing only a limited amount of the cathodic product of their respective reactions. One possible explanation on the limited chemical reversibility is that oxidation of $\mathrm{Se}(0)$ produced from the reduction processes mediated by galena is slow and irreversible. Another possibility is the loss of a fraction of cathodically produced $\mathrm{H}_{2}$ Se to the solution (and maybe gas) phase which has been reported in a number of studies employing CV coupled with electrochemical quartz crystal microbalance [20,22,24,25].

The stability of $\mathrm{Se}(-\mathrm{II})$ species increases at more negative potentials where $\mathrm{Se}(0)$ is reduced further into $\mathrm{HSe}^{-}$and $\mathrm{H}_{2}$ Se as inferred from the peak assignment of peak $\mathbf{C}_{2}$ and $\mathbf{C}_{3}$ (Sections 3.2 and 3.3). From voltammetry, a fraction of $\mathrm{H}_{2}$ Se produced via $\mathrm{C}_{3}$ diffuses away from the reacting volume around the electrode surface and the rest is retained on the surface as indicated by the low $C_{F} / C_{R}$ of $\sim 0.14$ and the positive $\Delta \mathrm{G}_{\mathrm{ads}}$. Retention of otherwise soluble $\mathrm{H}_{2} \mathrm{Se}$ would be due to the presence of red $\mathrm{Se}(0)$ due to its capability of strongly adsorbing Se(-II) species [59].

\subsection{Geochemical Implications}

In this study, electrochemical measurements are used to evaluate possible Se redox processes mediated by galena under reducing ( $\mathrm{Eh}+0.3$ to $-0.6 \mathrm{~V}$ ) and acidic (mainly, a $\mathrm{pH}$ of 4.6 ) conditions. $\mathrm{HSeO}_{3}{ }^{-}$is the dominant Se species with an oxidation state of $+\mathrm{IV}$ and is found redox-active under these conditions. The cyclic voltammetry measurements combined with XPS analysis reveal the potential-dependent reduction of $\mathrm{Se}(\mathrm{IV})$ to $\mathrm{Se}(0)$ and further to a mixed phase of $\mathrm{Se}(0)$ and $\mathrm{Se}(-\mathrm{II})$ at the galena surface where $\mathrm{Se}(0)$ is the main product of Se reduction under intermediate reducing conditions $\left(\mathrm{Eh}=-125 \mathrm{mV}\right.$ ) while the formation of $\mathrm{HSe}^{-}$and $\mathrm{H}_{2}$ Se results from reduction of $\mathrm{Se}(0)$ at highly reducing conditions $(-440$ to $-490 \mathrm{mV})$.

Equilibrium redox potentials (and potentials adjusted for adsorption contributions) and limited chemical reversibility of redox pairs $\mathrm{Se}^{0} / \mathrm{HSe}^{-}$and $\mathrm{Se}^{0} / \mathrm{H}_{2} \mathrm{Se}$ observed with cyclic voltammetry indicate that protonated $\mathrm{Se}(-\mathrm{II})$ species would be the dominant products of $\mathrm{Se}(\mathrm{IV})$ reduction. Since $\mathrm{Pb}(\mathrm{II})$ is generated from mineral dissolution in environmental systems involving galena, the formation of $\mathrm{Pb}(\mathrm{II}) / \mathrm{Se}(-\mathrm{II})$ solids such as clausthalite $(\mathrm{PbSe})$ is likely to occur in such settings where the adsorbed/dissolved Se(-II) species are produced from Se reduction which subsequently react with $\mathrm{Pb}$ (II).

The abiotic reduction of redox-sensitive elements can be mediated by a semiconducting mineral surface when the reduction is coupled with the oxidation of other species on the surface [37,63]. While in the electrochemical part of this study, electron transfer is triggered by applying an electrical potential, the mineral surface oxidation or the adsorption of reductants from solution to the surface plays an equivalent role in natural systems [64]. In a system where acidic dissolution of galena occurs in the presence of dissolved Se(IV), adsorbed or structural S(-II) species such as $\mathrm{H}_{2} \mathrm{~S}_{\text {and } \mathrm{HS}^{-}}$ may be possible sources for electrons being transferred through the galena surface to Se(IV). Similar mechanisms have been suggested from previous studies where reductants are sourced from the main constituent ions of the mineral catalyst $[62,65]$. 


\section{Conclusions}

One important finding from our computational modeling for Se species adsorbed on galena is that Se redox thermodynamics is influenced by interaction with the galena surface, revealing shifts in observed redox potentials relative to equilibrium redox potentials and our modeling evaluation suggests that this is caused by the contribution of adsorption Gibbs free energies. Specifically, the redox potential is calculated to shift towards more negative or positive values by 70 to $180 \mathrm{mV}$, depending on the $\Delta \mathrm{G}$ changes of adsorption of different Se redox reactions mediated via the galena surface (Table 2).

Our experimental and computational results contribute toward a fundamental understanding of the catalysis of redox transformations occurring at the mineral surface and is critical in evaluating Se fate and mobility in the environments. The computational approaches of this study have broad applications and can be applied to future studies that aim at accounting for energetic variations caused by interaction of chemical species with mineral surfaces, for instance, upon electrochemical and spectroscopic measurements.

Author Contributions: P.C. was primarily responsible for the electrochemical measurements with help from K.Y. and Y.K. XPS measurements were the responsibility of P.C., Y.K., and M.C.M., Y.K. and U.B. performed the computational work and U.B. had an advisory function over the entire project.

Funding: This research was funded by the U.S. National Science Foundation, Division of Earth Sciences, Grant No. EAR-1223976. Y.K. acknowledges support from Samsung Scholarship.

Conflicts of Interest: The authors declare no conflict of interest.

\section{References}

1. Dubrovsky, N.M.; Neil, J.M.; Fujii, R.; Oremland, R.; Hollibaugh, J. Influence of Redox potential on selenium distribution in ground-water, Mendota, western San-Joaquin Valley, California. US Geol. Surv. Open File Rep. 1990, 90138, 24.

2. $\mathrm{Wu}, \mathrm{L}$. Review of 15 years of research on ecotoxicology and remediation of land contaminated by agricultural drainage sediment rich in selenium. Ecotoxicol. Environ. Saf. 2004, 57, 257-269. [CrossRef]

3. Naftz, D.L.; Rice, J.A. Geochemical processes controlling selenium in ground water after mining, Powder River Basin, Wyoming, USA. Appl. Geochem. 1989, 4, 565-575. [CrossRef]

4. Clark, S.K.; Johnson, T.M. Selenium stable isotope investigation into selenium biogeochemical cycling in a lacustrine environment: Sweitzer Lake, Colorado. J. Environ. Qual. 2010, 39, 2200-2210. [CrossRef] [PubMed]

5. Yudovich, Y.E.; Ketris, M. Selenium in coal: A review. Int. J. Coal Geol. 2006, 67, 112-126. [CrossRef]

6. Martínez-Torrents, A.; Giménez, J.; Martínez-Lladó, X.; de Pablo, J.; Casas, I. Incorporation of selenium (IV) and selenium (VI) on uranyl peroxide. J. Radioanal. Nucl. Chem. 2015, 303, 153-159. [CrossRef]

7. Bott, A.W. Electrochemistry of semiconductors. Curr. Sep. 1998, 17, 87-92.

8. Rosso, K.M.; Becker, U. Proximity effects on semiconducting mineral surfaces II: Distance dependence of indirect interactions. Geochim. Cosmochim. Acta 2003, 67, 941-953. [CrossRef]

9. Arumugam, K.; Renock, D.; Becker, U. The basis for reevaluating the reactivity of pyrite surfaces: Spin states and crystal field d- orbital splitting energies of bulk, terrace, edge, and corner Fe( II) ions. PCCP 2019, 21, 6415-6431. [CrossRef]

10. Renock, D.; Becker, U. A first principles study of the oxidation energetics and kinetics of realgar. Geochim. Cosmochim. Acta 2010, 74, 4266-4284. [CrossRef]

11. Becker, U.; Rosso, K.M.; Hochella, M.F. The proximity effect on semiconducting mineral surfaces: A new aspect of mineral surface reactivity and surface complexation theory? Geochim. Cosmochim. Acta 2001, 65, 2641-2649. [CrossRef]

12. Skomurski, F.N.; Shuller, L.C.; Ewing, R.C.; Becker, U. Corrosion of UO2 and ThO2: A quantum-mechanical investigation. J. Nucl. Mater. 2008, 375, 290-310. [CrossRef]

13. Taylor, S.D.; Becker, U.; Rosso, K.M. Electron Transfer Pathways Facilitating U(VI) Reduction by Fe(II) on Alvs Fe-Oxides. J. Phys. Chem. C 2017, 121, 19887-19903. [CrossRef] 
14. Taylor, S.D.; Marcano, M.C.; Rosso, K.M.; Becker, U. An experimental and ab initio study on the abiotic reduction of uranyl by ferrous iron. Geochim. Cosmochim. Acta 2015, 156, 154-172. [CrossRef]

15. Grundl, T.J.; Haderlein, S.; Nurmi, J.T.; Tratnyek, P.G. Introduction to Aquatic Redox Chemistry. In Aquatic Redox Chemistry; Tratnyek, P.G., Grundl, T.J., Haderlein, S.B., Eds.; American Chemical Society: Columbus, OH, USA, 2011; Volume 1071, pp. 1-632.

16. Gorski, C.A.; Nurmi, J.T.; Tratnyek, P.G.; Hofstetter, T.B.; Scherer, M.M. Redox behavior of magnetite: Implications for contaminant reduction. Environ. Sci. Technol. 2009, 44, 55-60. [CrossRef]

17. Pridmore, D.; Shuey, R. The electrical resistivity of galena, pyrite, and chalcopyrite. Am. Mineral. 1976, 61, 248-259.

18. Renock, D.; Becker, U. A first principles study of coupled substitution in galena. Ore Geol. Rev. 2011, 42, 71-83. [CrossRef]

19. Bougouma, M.; Van Elewyck, A.; Steichen, M.; Buess-Herman, C.; Doneux, T. Selenium electrochemistry in choline chloride-urea deep eutectic electrolyte. J. Solid State Electrochem. 2013, 17, 527-536. [CrossRef]

20. Cabral, M.F.; Pedrosa, V.A.; Machado, S.A.S. Deposition of selenium thin layers on gold surfaces from sulphuric acid media: Studies using electrochemical quartz crystal microbalance, cyclic voltammetry and AFM. Electrochim. Acta 2010, 55, 1184-1192. [CrossRef]

21. Ivandini, T.A.; Einaga, Y. Electrochemical detection of selenium (IV) and (VI) at gold-modified diamond electrodes. Electrocatalysis 2013, 4, 367-374. [CrossRef]

22. Kowalik, R. Microgravimetric studies of selenium electrodeposition onto different substrates. Arch. Metall. Mater. 2014, 59, 871-877. [CrossRef]

23. Maranowski, B.; Strawski, M.; Osowiecki, W.; Szklarczyk, M. Study of selenium electrodeposition at gold electrode by voltammetric and rotating disc electrode techniques. J. Electroanal. Chem. 2015, 752, 54-59. [CrossRef]

24. Solaliendres, M.; Manzoli, A.; Salazar-Banda, G.; Eguiluz, K.; Tanimoto, S.; Machado, S. The processes involved in the Se electrodeposition and dissolution on Au electrode: $\mathrm{The}_{2} \mathrm{H}_{2} \mathrm{Se}$ formation. J. Solid State Electrochem. 2008, 12, 679-686. [CrossRef]

25. Wei, C.; Myung, N.; Rajeshwar, K. A combined voltammetry and electrochemical quartz crystal microgravimetry study of the reduction of aqueous Se (IV) at gold. J. Electroanal. Chem. 1994, 375, 109-115. [CrossRef]

26. Feliu, J.; Gómez, R.; Llorca, M.; Aldaz, A. Electrochemical behavior of irreversibly adsorbed selenium dosed from solution on $\mathrm{Pt}(\mathrm{h}, \mathrm{k}, \mathrm{l})$ single crystal electrodes in sulphuric and perchloric acid media. Surf. Sci. 1993, 289, 152-162. [CrossRef]

27. Santos, M.C.; Machado, S.A. Microgravimetric, rotating ring-disc and voltammetric studies of the underpotential deposition of selenium on polycrystalline platinum electrodes. J. Electroanal. Chem. 2004, 567, 203-210. [CrossRef]

28. Kazacos, M.S.; Miller, B. Studies in selenious acid reduction and CdSe film deposition. J. Electrochem. Soc. 1980, 127, 869-873. [CrossRef]

29. Curti, E.; Aimoz, L.; Kitamura, A. Selenium uptake onto natural pyrite. J. Radioanal. Nucl. Chem. 2013, 295, 1655-1665. [CrossRef]

30. Han, D.S.; Batchelor, B.; Abdel-Wahab, A. Sorption of selenium (IV) and selenium (VI) onto synthetic pyrite (FeS2): Spectroscopic and microscopic analyses. J. Colloid Interface Sci. 2012, 368, 496-504. [CrossRef]

31. Martinez, M.; Gimenez, J.; De Pablo, J.; Rovira, M.; Duro, L. Sorption of selenium (IV) and selenium (VI) onto magnetite. Appl. Surf. Sci. 2006, 252, 3767-3773. [CrossRef]

32. Naveau, A.; Monteil-Rivera, F.; Guillon, E.; Dumonceau, J. Interactions of aqueous selenium (- II) and (IV) with metallic sulfide surfaces. Environ. Sci. Technol. 2007, 41, 5376-5382. [CrossRef] [PubMed]

33. Kim, B.S.; Hayes, R.; Prestidge, C.; Ralston, J.; Smart, R.S.C. Scanning tunnelling microscopy studies of galena: The mechanism of oxidation in air. Appl. Surf. Sci. 1994, 78, 385-397. [CrossRef]

34. Laajalehto, K.; Kartio, I.; Heinonen, M.; Laiho, T. Temperature Controled Photoelectron Spectroscopic Investigation of Volatile Species on PbS (100) Surface. Jpn. J. Appl. Phys. 1999, 38, 265. [CrossRef]

35. Wittstock, G.; Kartio, I.; Hirsch, D.; Kunze, S.; Szargan, R. Oxidation of galena in acetate buffer investigated by atomic force microscopy and photoelectron spectroscopy. Langmuir 1996, 12, 5709-5721. [CrossRef]

36. Cha, C.S.; Li, C.M.; Yang, H.; Liu, P. Powder microelectrodes. J. Electroanal. Chem. 1994, 368, 47-54. [CrossRef] 
37. Renock, D.; Mueller, M.; Yuan, K.; Ewing, R.C.; Becker, U. The energetics and kinetics of uranyl reduction on pyrite, hematite, and magnetite surfaces: A powder microelectrode study. Geochim. Cosmochim. Acta 2013, 118, 56-71. [CrossRef]

38. Moulder, J.F. Handbook of X-ray Photoelectron Spectroscopy: A Reference Book of Standard Spectra for Identification and Interpretation of XPS Data; Physical Electronics Division, Perkin-Elmer Corporation: Waltham, MA, USA, 1992.

39. Becke, A.D. Density-functional thermochemistry. III. The role of exact exchange. J. Chem. Phys. 1993, 98, 5648-5652. [CrossRef]

40. Lee, C.; Yang, W.; Parr, R.G. Development of the Colle-Salvetti correlation-energy formula into a functional of the electron density. Phys. Rev. B 1988, 37, 785. [CrossRef]

41. Dunning Jr, T.H. Gaussian basis sets for use in correlated molecular calculations. I. The atoms boron through neon and hydrogen. J. Chem. Phys. 1989, 90, 1007-1023. [CrossRef]

42. Dunning, T.H.; Hay, P.J. Gaussian basis sets for molecular calculations. In Methods of Electronic Structure Theory; Springer: Berlin/Heidelberg, Germany, 1977; pp. 1-27.

43. Wadt, W.R.; Hay, P.J. Ab initio effective core potentials for molecular calculations. Potentials for main group elements Na to Bi. J. Chem. Phys. 1985, 82, 284-298. [CrossRef]

44. Urban, D.R.; Wilcox, J. A theoretical study of properties and reactions involving arsenic and selenium compounds present in coal combustion flue gases. J. Phys. Chem. A 2006, 110, 5847-5852. [CrossRef] [PubMed]

45. Anderson, B.; Becker, U.; Helean, K.; Ewing, R. Perrhenate and pertechnetate behavior on iron and sulfur-bearing compounds. In Proceedings of the symposium on Scientific Basis for Nuclear Waste Management XXX, Boston, MA, USA, 27 November 2006.

46. Becker, U.; Hochella Jr, M.F.; Vaughan, D.J. The adsorption of gold to galena surfaces: Calculation of adsorption/reduction energies, reaction mechanisms, XPS spectra, and STM images. Geochim. Cosmochim. Acta 1997, 61, 3565-3585. [CrossRef]

47. Tomasi, J.; Mennucci, B.; Cammi, R. Quantum mechanical continuum solvation models. Chem. Rev. 2005, 105, 2999-3093. [CrossRef] [PubMed]

48. Gardner, J.; Woods, R. A study of the surface oxidation of galena using cyclic voltammetry. J. Electroanal. Chem. Interfacial Electrochem. 1979, 100, 447-459. [CrossRef]

49. Higgins, S.; Hamers, R. Spatially-resolved electrochemistry of the lead sulfide (galena)(001) surface by electrochemical scanning tunneling microscopy. Surf. Sci. 1995, 324, 263-281. [CrossRef]

50. Pritzker, M.; Yoon, R. A voltammetric study of galena immersed in acetate solution at pH 4.6. J. Appl. Electrochem. 1988, 18, 323-332. [CrossRef]

51. Huang, B.M.; Lister, T.E.; Stickney, J.L. Se adlattices formed on Au (100), studies by LEED, AES, STM and electrochemistry. Surf. Sci. 1997, 392, 27-43. [CrossRef]

52. Bard, A.J.; Faulkner, L.R.; Leddy, J.; Zoski, C.G. Electrochemical methods: Fundamentals and applications; Wiley: New York, NY, USA, 1980; Volume 2.

53. Bouroushian, M. Electrochemistry of the Chalcogens. In Electrochemistry of Metal Chalcogenides; Springer: Berlin/Heidelberg, Germany, 2010; pp. 57-75.

54. Bylaska, E.J.; Salter-Blanc, A.J.; Tratnyek, P.G. One-electron reduction potentials from chemical structure theory calculations. In Aquatic Redox Chemistry; ACS Publications: Washington, DC, USA, 2011; pp. 37-64.

55. Pavitt, A.S.; Bylaska, E.J.; Tratnyek, P.G. Oxidation potentials of phenols and anilines: Correlation analysis of electrochemical and theoretical values. Environ. Sci. Process. Impacts 2017, 19, 339-349. [CrossRef]

56. Salter-Blanc, A.J.; Bylaska, E.J.; Johnston, H.J.; Tratnyek, P.G. Predicting reduction rates of energetic nitroaromatic compounds using calculated one-electron reduction potentials. Environ. Sci. Technol. 2015, 49, 3778-3786. [CrossRef]

57. Rupp, H.; Weser, U. X-ray photoelectron spectroscopy of some selenium containing amino acids. Bioinorg. Chem. 1975, 5, 21-32. [CrossRef]

58. Chen, Y.-W.; Li, L.; D’Ulivo, A.; Belzile, N. Extraction and determination of elemental selenium in sediments-A comparative study. Anal. Chim. Acta 2006, 577, 126-133. [CrossRef] [PubMed]

59. Nuttall, K.L.; Allen, F.S. Hydrogen selenide ion adsorption to colloidal elemental selenium. Inorg. Chim. Acta 1984, 89, 199-201. [CrossRef] 
60. Scheinost, A.C.; Kirsch, R.; Banerjee, D.; Fernandez-Martinez, A.; Zaenker, H.; Funke, H.; Charlet, L. X-ray absorption and photoelectron spectroscopy investigation of selenite reduction by FeII-bearing minerals. J. Contam. Hydrol. 2008, 102, 228-245. [CrossRef] [PubMed]

61. Espinosa, A.; Tascón, M.; Vázquez, M.; Batanero, P.S. Electroanalytical study of selenium (+ IV) at a carbon paste electrode with electrolytic binder and electroactive compound incorporated. Electrochim. Acta 1992, 37, 1165-1172. [CrossRef]

62. Scheinost, A.C.; Charlet, L. Selenite reduction by mackinawite, magnetite and siderite: XAS characterization of nanosized redox products. Environ. Sci. Technol. 2008, 42, 1984-1989. [CrossRef] [PubMed]

63. Yuan, K.; Renock, D.; Ewing, R.C.; Becker, U. Uranium reduction on magnetite: Probing for pentavalent uranium using electrochemical methods. Geochim. Cosmochim. Acta 2015, 156, 194-206. [CrossRef]

64. Kim, Y.; Yuan, K.; Ellis, B.R.; Becker, U. Redox reactions of selenium as catalyzed by magnetite: Lessons learned from using electrochemistry and spectroscopic methods. Geochim. Cosmochim. Acta 2017, 199, 304-323. [CrossRef]

65. Kang, M.; Chen, F.; Wu, S.; Yang, Y.; Bruggeman, C.; Charlet, L. Effect of pH on aqueous Se (IV) reduction by pyrite. Environ. Sci. Technol. 2011, 45, 2704-2710. [CrossRef]

(C) 2019 by the authors. Licensee MDPI, Basel, Switzerland. This article is an open access article distributed under the terms and conditions of the Creative Commons Attribution (CC BY) license (http://creativecommons.org/licenses/by/4.0/). 